\title{
In Memoriam: A Tribute to Professor Daniel J. Freed
}

Yale Law Professor Daniel J. Freed, a cofounder of Federal Sentencing Reporter and a Vera trustee for nearly forty years, is a legendary figure in the worlds of sentencing, bail, and criminal justice generally. With his gentle but incisive approach, Dan was-and still is — a moral and intellectual North Star for generations of lawyers, judges, professors, and criminal justice policymakers. No collection of articles or stories about Vera and sentencing would be complete without a discussion of Dan. Thus, it is fitting to conclude this special issue of FSR with a tribute to Dan Freed the reformer, the scholar, the colleague, the teacher, and the cherished friend.

Judge (ret.)

Professor,

Harvard Law School

\section{SOFIA}

\section{YAKREN}

Practitioner in

Residence,

Women and the

Law Clinic,

American University

Washington College of Law
Kate Stith: Daniel J. Freed, who was born in New York on May I2, I927, died in that city on January I7, 2010, of renal failure. He left his wife, Judy, sons Peter and Jonathan, daughters Amy and Emily, and six grandchildren-the youngest of whom was born just in time to meet and give joy to her grandfather a few days before he died with his whole family surrounding him.

Dan Freed received his B.S. in 1948 from Yale and his LL.B. in I95I from Yale Law School, where he was a Note editor of the Yale Law Journal. His interest in criminal law sparked in his final term as a law student, when he took on (as an extracurricular activity) a theft case for the New Haven Legal Aid Society. Dan conducted his own investigation and concluded that the defendant had been set up by a family member, and he was stunned when the defendant nonetheless chose to take the lenient plea-agreement offered by the prosecution. Thus began a lifetime devoted to reforming institutions of criminal justice. While Dan first practiced tax law, he was simultaneously an activist in the Washington, D.C., Bar, spurring a variety of reform efforts. Under Attorney General Robert Kennedy (and alongside the late, great Burke Marshall), he was appointed to help form the Office of Criminal Justice at the Department, which was the incubator of many reforms that last to this day. In I964, with his Yale Law School classmate Patricia M. Wald, he wrote Bail in the United States, which is recognized to be the basis of the landmark federal Bail Reform Act of 1966.

In I969, Yale Law School decided, amid much student agitation, to offer clinical activities for credit and Dan was appointed Professor of Criminal Law and Its Administration to oversee development of Yale's clinical courses. Dan soon brought on Professors Stephen Wizner and Jay Pottenger. Once Steve and Jay were here to bring students into the real world with the Danbury Prison Project and a variety of legal aid clinics, Dan was freed to bring the real world to Yale Law School. One of his early projects was the Sentencing Workshop, at which state and federal judges considered, with students, how real offenders (with names redacted) should be sentenced. As Dean Robert Post remarked at Dan's memorial service:

It is fair to say that Dan pioneered the study of sentencing — as both a scholarly subject and a practical one. He challenged his students to engage not only with doctrine but also with real social change, to understand not only the law as written but also the people who administered it, to believe in law reform but also to critically evaluate it. He approached [his] work... "with a skeptical eye and a generous heart."

Daniel Wilhelm of the Vera Institute of Justice in New York City, which worked with Dan Freed for decades, further explained his influence in a tribute published several years ago: Dan "eschew[ed] polemics" even as he appreciated "the central role that politics plays" in criminal justice policy.

Dan was teaching his Sentencing Workshop when Congress enacted the Sentencing Reform Act of 1984 , which created the U.S. Sentencing Commission with instructions on issuing sentencing guidelines. Along with his close friend and colleague Professor Dennis Curtis, Dan had been an early proponent of sentencing guidelines. But Dan and Denny were shocked when they read the initial draft guidelines in 1986; the final version, though it had been infused with more flexibility by Commissioner (and Judge) Stephen Breyer, still disappointed Dan greatly.

In the late I980s, Dan and Professor Marc Miller founded Federal Sentencing Reporter, and in 1994 Dan published his own critique and recommendations for reform. The theme is in his title: "Federal Sentencing in the Wake of Guidelines: Unacceptable Limits on the Discretion of

Federal Sentencing Reporter, Vol. 24, No. I, pp. 82-84, ISSN 1053-9867 electronic ISSN 1533-8363. (C) 20II Vera Institute of Justice. All rights reserved. Please direct requests for permission to photocopy or reproduce article content through the University of California Press's Rights and Permissions website, http://www.ucpressjournals.com/reprintInfo.asp. DOI: IO.I525/fsr.20II.24.I.82. 
Sentencers." In my view, if we want to find a single, preeminent reason the federal sentencing guidelines are so ridiculously complicated on paper and disingenuously followed in practice, it is because Dan Freed was not in the room when they were developed.

In addition to his work on bail and sentencing, Dan examined drug policy (again, often through workshops that brought in the real world by inviting police, medical professionals, and recovering drug addicts to participate) and other criminal justice issues. He served until his final illness as a trustee of the Vera Institute of Justice.

Ultimately, Dan had impact not only because of the power of his ideas but also because of his character and his belief in the good faith and capabilities of policymakers, officials, citizens, and students. We appreciate all he did, and we miss him terribly.

Nancy Gertner: It was 1998, and I had been a judge for almost five years. To be candid, I was struggling. Not with the work; I had taught law and practiced for decades. I was struggling with sentencing defendants and I was thinking seriously about leaving the bench. The U.S. Sentencing Guidelines and mandatory minimum sentencing laws seemed to reduce human beings to ill-fitting and palpably unjust categories. Judges were expected to follow the rules, all the while intoning, "I have no choice but to sentence you to twenty years for a minor crack distribution offense because you have two prior equally minor distribution offenses," or "I have no choice but to label you a career offender after a series of drug-addled but nonviolent crime sprees." It seemed not to matter that such sentences imposed real injustice to individuals and real costs to mass incarceration.

I wrote decisions, trying to carve out meaningful distinctions within the structure of the Sentencing Guidelines, but I had little support or encouragement until I was invited to participate in Dan's sentencing workshop. Also invited were other judges, prosecutors, probation officers, defense lawyers, and Dan's students and colleagues. The visitors were obligated to participate in three workshops, an extraordinary amount of time for busy judges. It was my first encounter with what Dan expected of us-nothing less than the commitment he himself showed.

Most central to his method were the hypothetical sentencing cases that he gave to all of us. Everyone sentenced and exchanged their sentences before class. Everyone was charged with reading each other's work. The sentences were posted in the hope that the reasoning of others would challenge us to reconsider our own. What had seemed like simple issues suddenly had many complex layers. I was participating in conversations about sentencing dimensions more sophisticated and nuanced than any I had heard in my courtroom or at judicial conferences. I was hooked—now a zealous Freedian.

The next semester Dan asked me to teach and I gladly accepted. It was a challenge, to be sure. I had been teach- ing for over three decades, when I was a practicing lawyer and even a judge, but his teaching was different. He e-mailed students about their sentencing prospectuses, pages and pages of comments and suggestions, all characteristically littered with points of praise for the work they had done and the promise of what was yet to be. Even though Dan had been teaching this course for years, the materials were constantly reexamined; every semester, the approaches changed.

It should come as no surprise that numbers of students wrote articles that were then published, or went on to become law professors or policymakers. It should come as no surprise that when you do a "Dan Freed" Lexis search you get not only his works but also acknowledgments from students and colleagues who were inspired by him. It should come as no surprise that the judges we taught at a program sponsored by the Federal Judicial Center are now writing the most interesting opinions.

I sit in Dan's office. I sit with his books and papers from a career at Yale that stretches from the I970s. I can say without equivocation that whatever I have done in this field, whatever differences I have made, I owe to Dan. I miss him and love him deeply.

Sofia Yakren: My reverence for Professor Freed as a scholar, teacher, and human being has only grown since his memorial service. At the time, I spoke from the vantage point of an ever-grateful, ever-transformed former student. Having now completed my first year of teaching in a law school clinical program, I write with the regard and awe of a colleague. Perhaps it is no coincidence that, in 1969, Professor Freed began his teaching career by launching Yale's first clinical program to grant academic credit for supervised student work in real-world settings. Professor Freed's pioneering efforts have afforded me the opportunity to experience firsthand the glorious challenges of guiding students through complicated intellectual terrain with real-world implications, while remaining mindful of students' personal and emotional needs. Prioritizing the former over the latter could well simplify the teaching process, but Professor Freed embodied and expected better. I hope he remains a guiding force for extending ourselves to nurture and enhance the multidimensions of those lives in our midst.

In 2002, I was a first-year student at Yale Law School-intimidated and sure only of my inadequacy. I enrolled in a sentencing class designed for second- and third-year students to engage in sophisticated thinking about federal sentencing reform alongside Professors Freed, Dennis Curtis, and Kate Stith, as well as Judge Nancy Gertner. I understood Professor Freed agreed to admit me as a first-year student against his better judgment, which only compounded my trepidation. I never expected that, in time, this bowtie-sporting sentencing guru would become one of my greatest sources of validation and confidence. I would have settled for some intellectual growth, but Professor Freed transcended all 
that might have kept him from becoming my mentor and offered so much more than I could have imagined.

Through gestures large and small, Professor Freed transformed his tentative students into scholars worthy of discourse with him. I recently reviewed some of Professor Freed's old e-mails to students and found them replete with messages about how we each, and our ideas, mattered. Professor Freed's words and actions practically form a how-to guide on empowering insecure law students by giving them faith in their own capacity to make worldchanging contributions.

In our exchanges regarding a paper I was writing under his tutelage, Professor Freed embedded subtle lessons about my capacity to make valuable contributions. He provided intellectual support such that I did not feel isolated in the pursuit while also giving me space to develop my own ideas. Even from afar, Professor Freed delved into the material with me, reading cases I found most interesting or troubling, reacting to my analyses, and offering his own theories. We were equals trying to make sense of convoluted jurisprudence.

And, at every turn, even when other demands temporarily trumped my work on the paper, Professor Freed was kind and understanding, offering help without judgment. He never forgot the importance of life beyond the intellectual pursuit, referencing wonderful travel adventures with his wife and children alongside ideas for sentencing reform. Professor Freed encouraged his students' intellect, but cared about us as whole people.
Professor Freed treated his students like colleagues; he included us in panels with judges and leading academics, and he solicited our recommendations to the Sentencing Commission and our ideas about articles long after our courses with him had ended. By envisioning us as valuable participants, he made us so.

In the quietly demanding halls of Yale Law School, we were seen, heard, and affirmed by at least one important man. And, out in the world beyond law school, we continued to have his support. A 2003 Yale Law School graduate recently wrote to me,

In addition to setting me on the path to becoming a federal defender, Prof. Freed - without my askinghelped me secure my clerkships and current job. He never told me what he did, but after the fact, my employers mentioned my persistent professor. He looked over so many of us-and did so because he really cared. He was wonderfully supportive, an amazing mentor, and so warm....

In caring about the details of our lives, Professor Freed gave so much to generations of his students. He devoted himself to study and analysis with grace and goodness, not at the expense of human connection, but in furtherance of it. We carry with us and hope to emulate his intellectual integrity, his kindness, his devotion to the human spirit. Because of him, we have greater faith in ourselves and remember that no gesture is too small to make another feel seen, valued, and forever changed. 